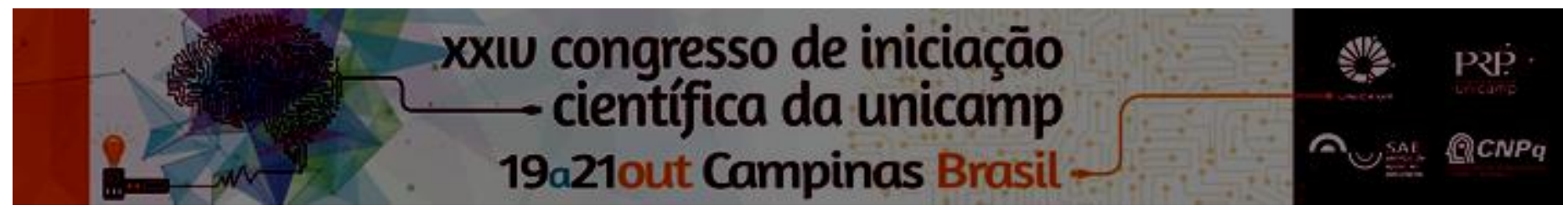

\title{
Estudo sobre o Grau de Alavancagem Financeira das empresas de Capital Aberto no Brasil no período de 2005 a 2014.
}

\section{Carolina L. Gomes*, Márcio M.}

\section{Resumo}

O trabalho em questão teve como objetivo analisar o grau de alavancagem financeira (GAF) das empresas brasileiras de capital aberto que compõem o Índice Bovespa, utilizando os dados de 48 empresas durante os anos de 2005 a 2014.

\section{Palavras-chave:}

Alavancagem financeira, Price-to-book Value, Endividamento.

\section{Introdução}

Esse trabalho teve como objetivo analisar o grau de alavancagem financeira das empresas de capital aberto no período de 2005 a 2014. As empresas de capital aberto são aquelas cujos valores mobiliários, ações e debêntures, são negociados em mercados públicos organizados. Foram utilizados dados das empresas componentes da carteira teórica do lbovespa de maio de 2016.

Em relação ao conceito de Alavancagem Financeira utilizou-se aquele que define a alavancagem como a capacidade que os recursos de terceiros têm de influenciar os resultados líquidos da empresa, isto é, o resultado da participação de terceiros na estrutura de capital da empresa, pode modificar o lucro do período.

\section{Resultados e Discussão}

Essa pesquisa pode ser considerada exploratória, bibliográfica e ex-post-facto.

Para analisar até que ponto as variáveis price-to-book valeu (PBV) e Endividamento (END) se relacionavam com o GAF, foi utilizado uma técnica de análise multivariada de regres são linear, sendo que PBV é o preço de mercado da empresa e o END é a relação entre capital de terceiros e patrimônio líquido da empresa.

Relacionando essas duas variáveis com o GAF, foi possível analisar o relacionamento entre elas e suas correlações. A amostra considerada foram 48 empresas que compõe o Ibov.

Depois de analisados os resultados obtidos no período, através das evidências preliminares e da análise estatística implementada, pode-se afirmar à luz das limitações impostas pela metodologia adotada que a variável estudada, grau de alavancagem financeira (GAF), não possui relação com as variáveis endividamento (END) e price-to-book value (PBV).

Durantes as análises das médias e dos gráficos, ficou evidente que o comportamento das variáveis durante 0 período não possui relação estreita.
Figura 1. Grau de Alavancagem Financeira

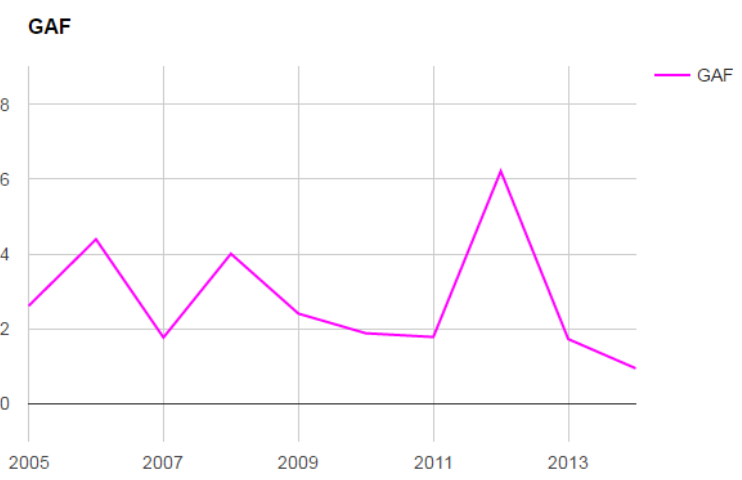

\section{Conclusão}

Após analisados os dados, nota-se que a variável em estudo (GAF), não apresentou correlação com endividamento no período estudado para as empresas da amostra.

Notou-se também que o valor do GAF, durante o período em questão, comportou-se de maneira instável, apresentando aumentos e quedas.

Após analisados os índices de correlação entre END x GAF e PBV x GAF, é possível afirmar que as variáveis endividamento e preço de mercado não explicam o comportamento do GAF, sendo assim, a conclusão que se chega é que o grau de alavancagem financeiro pode ser influenciado por outras variáveis, como por exemplo, nível de atividade, nível dos juros básicos e outras variáveis ambientais.

Esta pesquisa não teve a intenção de esgotar o assunto e os resultados estão restritos à amostra no período. Recomenda-se futuras investigações com utilização de outras técnicas e outros períodos.

\section{Agradecimentos}

Gostaria de agradecer toda minha família, principalmente meus pais e meu irmão, por acreditarem em mim e por estarem sempre ao meu lado. Agradeço também meu orientador, pois sem ele, eu não teria conseguido concluir essa pesquisa.

Neto, Alexandre Assaf. 2012

Matarazzo, Dante C. $\mathbf{2 0 1 0}$

Ross, Stephen A. 2009

Jensen, Michael C.; Meckling, Wilian H. 1976 